\title{
Long-Term Effects of Vegetation Treatments in the Chaparral Transition Zone
}

\author{
Kelly N. Fuhrmann and Timothy E. Crews
}

$\mathrm{S}$ ince European settlement, the impacts of cattle production and wood harvesting in the West have affected the structure and transformed the composition of juniper-pinyon and chaparral. In the past, wildfires were more common in the juniper-pinyon and chaparral communities of the Southwest where they burned at intervals of 10 -30 years. The regular occurrence of fire appears to have restricted the establishment of woody species to more shallow, rocky soils on which grasses do not thrive.

The canopy cover and density of juniper-pinyon and chaparral can have a direct impact on the production of grasses and herbaceous plants. The removal of this canopy by various means has been implemented in many woody plant communities in an attempt to increase the production of herbaceous forage for livestock and habitat improvement for wildlife.

The main objective of the application of original herbicide, fire, and mechanical push vegetation treatments (applied in 1964-1981) sampled in this study was to encourage the growth of herbaceous vegetation for cattle production. The disturbances caused by the treatments were intended to, at a minimum, set succession back to a grass/forb community, or ideally to shift the community towards a stable more permanent herbaceous community. The three range treatment techniques were undertaken to improve the potential for herbaceous species to effectively compete with larger woody species in an ecosystem affected by climatic and edaphic constraints, and impacted by livestock grazing. Tree abundance, dominance, and cover were to be limited on chosen sites.

In 1997, we compared the effectiveness of herbicide, fire and mechanical push range treatment techniques decades after they were implemented. Long-term assessment is critical for both economic and ecological reasons. Economically, it is important to know how long "woodland conversion" range treatments last given the expense that can be incurred to implement them. Ecologically, it is important to monitor species diversity and abundance in posttreatment communities to evaluate the effects that different treatment methods have on biodiversity.

\section{Sites}

The herbicide, fire and mechanical push sites sampled are located on the east side of the Santa Maria Mountains in central Arizona (Map 1). All sampling sites have similar slope, aspect, elevation, and soils. This area has a warm, semiarid climate.
The vegetation communities of the east Santa Maria Mountains consist mainly of shrubby species including turbinella oak, manzanita, desert ceanothus, squawbush, mountain mahogany, wright's silktassel, and wait-a-minute bush. Dominant tree species include Utah juniper, single needle pinyon, and alligator juniper. Although generally sparse, the most frequently encountered native grasses include black grama, blue grama, sideoats grama, western needlegrass, and curly mesquite.

\section{Original Treatments}

\section{Herbicide Treatment}

A Pikloram (Torridon10-K) and Tebuthirone (Elancos Grassland) herbicide treatment, was aerially applied to 60 acres four times during the 1979 mid-summer monsoon season at one pound per acre in pellet dry form using a $10 \%$ chemical solution mixed with bentonite clay. Using instrumentation available at the time, residual traces of the herbicide were no longer detectable two months after the application in 1979. U.S. Forest Service records show that no reseeding was done after the herbicide application.

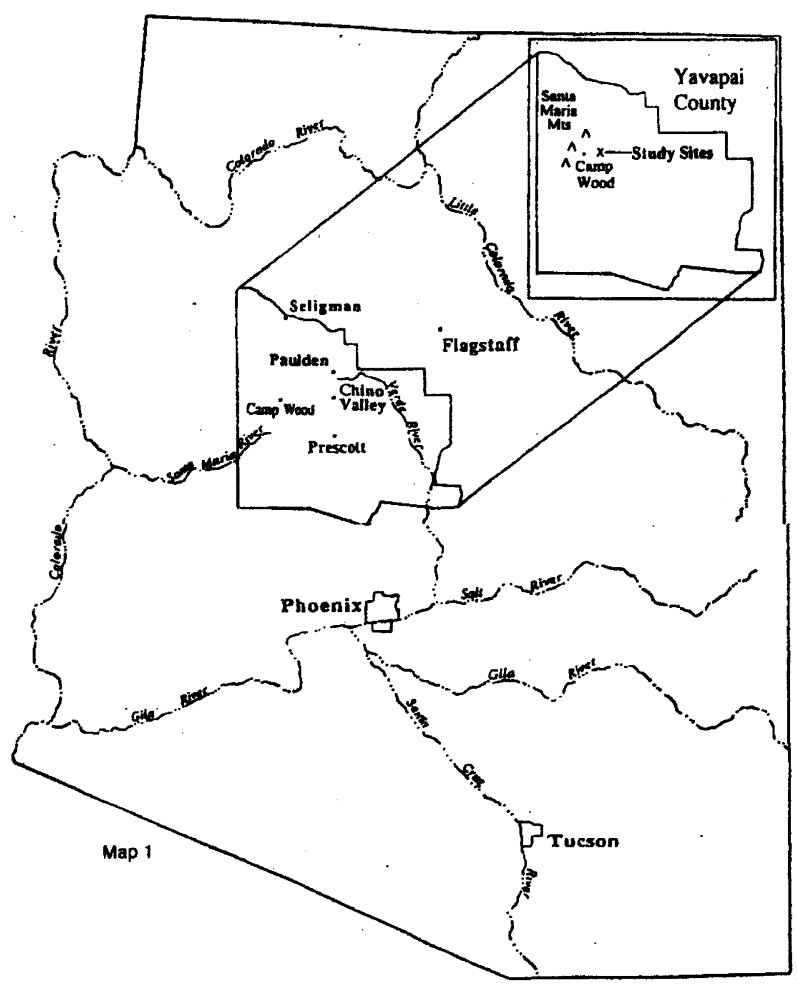




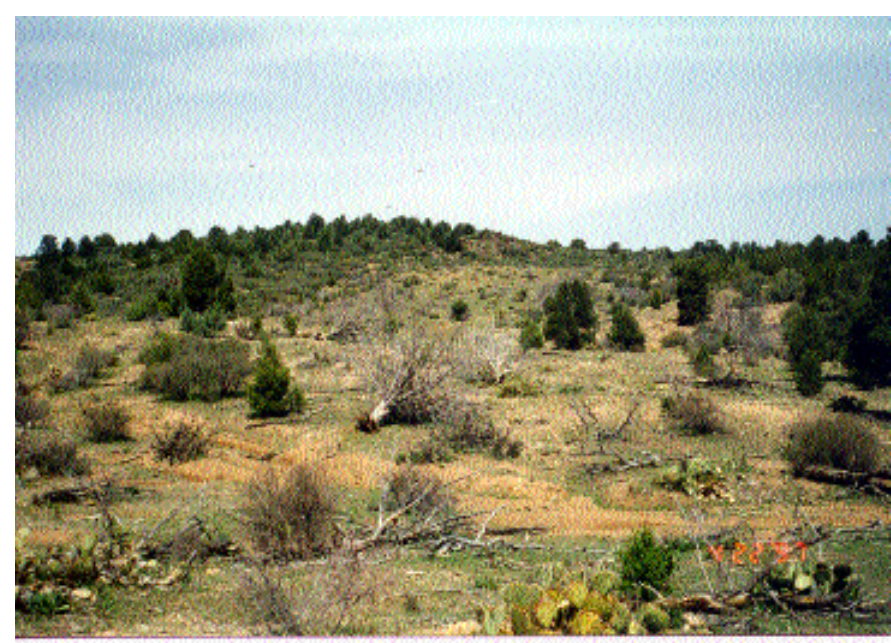

Herbicide treatment.

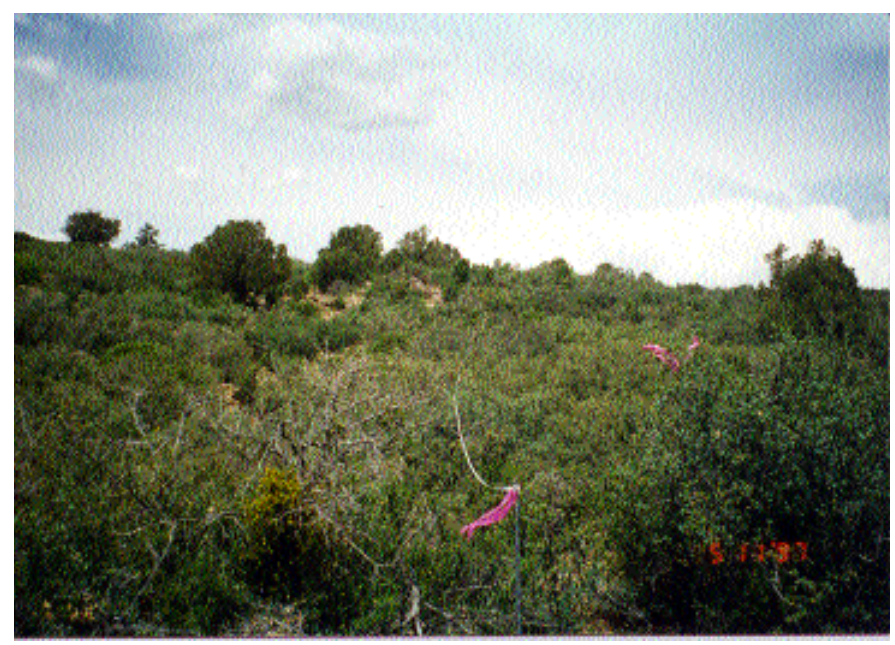

Prescribed burn treatment.

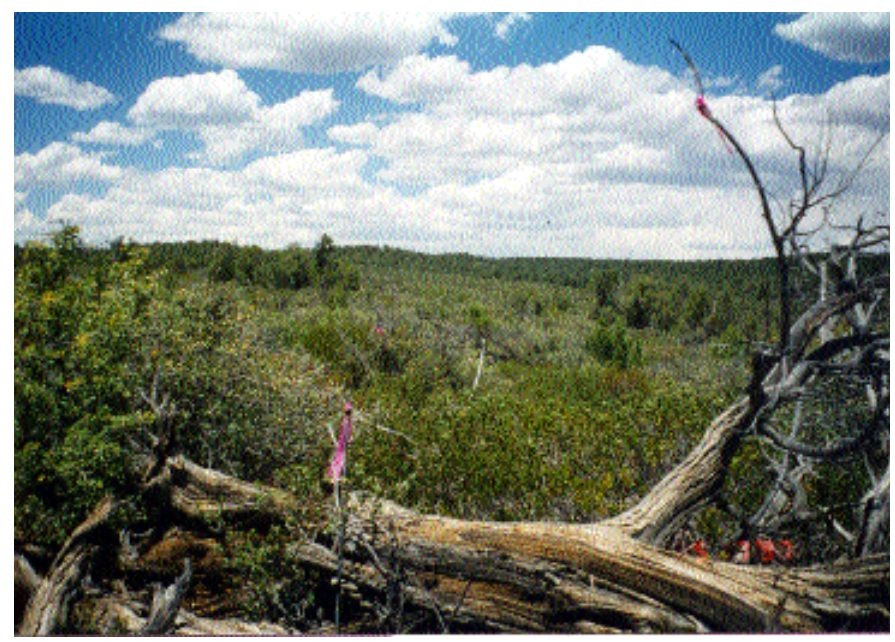

Mechanical push treatment.

\section{Prescribed Burn Treatment}

The prescribed burn (2200 acres), performed in the fall of 1981 was of moderate intensity, closely mimicking a natural fire for the vegetation type.

\section{Mechanical Push Treatment}

A 1964 mechanical push with a D-7 caterpillar (1100 acres) of mature juniper and pinyon trees, was completed during fall and winter of 1964 . Reseeding was attempted on the push treatment site with weeping lovegrass, and yellow blossom sweet clover. Both were applied at two pounds per acre.

\section{Evaluation}

Each of the three treated sites and adjacent control areas were evaluated in 1997. Basic vegetation sampling included: a 3.28 square foot frequency frame analysis for the determination of herbaceous cover frequency, bare soil and litter dispersion; Point-Center-Quarter analysis for tree density and frequency determination; a Crown Diameter analysis to determine percent crown cover area of tree species; and a Line Intercept method to measure percent of shrub cover by species over a 656 foot transect line.

Data obtained from the frequency frame and point-center -quarter field sampling methods were analyzed for significant differences using a standard two-tailed T-test.

\section{Effects of Treatments on Plant Community Attributes}

\section{Herbicide Treatment}

Of the three range treatments sampled for grass cover, only the herbicide treatment had significantly higher grass composition compared to the adjacent untreated control site vegetation (Table 1). The herbaceous composition on this study site consisted mainly of introduced annual grasses and forbs, especially cheatgrass and red brome. Introduced grasses found on the herbicide treatment were not present on the other sites. In the herbicide treatment, forbs appeared to be overshadowed by the more developed grass community. One exception was flannel mullein, which was quite prominent on this site because of its size. Flannel mullein is an exotic species, which is partial to disturbed ground but was not present on any of the other treatment or control sites. Because of heavy tree and shrub density, no forbs were recorded on the herbicide control site. Ground litter, which consists of previous season's undecomposed organic material, was more abundant directly under individual shrubs and the herbaceous canopy on the herbicide treatment site. It was very limited in the open areas between shrub and tree clusters. Litter frequency on the ground varied with canopy cover. The herbaceous canopy structure in the herbicide treatment appeared to be directly related to the encounter frequency $(28.5 \%)$ of litter on the ground. Interestingly, the bare soil component of this site was also comparatively high in certain areas. Although larger Utah juniper was more abundant than mature single needle piny- 
Table 1. Treatment and Control Site Measurements for Three Treatment Types

\begin{tabular}{|c|c|c|c|c|}
\hline & & Herbicide & Fire & $\begin{array}{l}\text { Mechanical } \\
\text { Push }\end{array}$ \\
\hline \multicolumn{5}{|c|}{$\begin{array}{l}\text { Grass Encounter } \\
\text { Frequency }(\%)\end{array}$} \\
\hline Sites: & $\begin{array}{l}\text { treatment } \\
\text { control }\end{array}$ & $\begin{array}{r}22 \\
0\end{array}$ & $\begin{array}{r}4.5 \\
.5\end{array}$ & $\begin{array}{l}0 \\
0\end{array}$ \\
\hline \multicolumn{5}{|c|}{$\begin{array}{l}\text { Forb Encounter } \\
\text { Frequency }(\%)\end{array}$} \\
\hline Sites: & $\begin{array}{l}\text { treatment } \\
\text { control }\end{array}$ & $\begin{array}{l}3 \\
0\end{array}$ & $\begin{array}{l}2 \\
5\end{array}$ & $\begin{array}{l}0 \\
0\end{array}$ \\
\hline \multicolumn{5}{|c|}{$\begin{array}{l}\text { Soil Encounter } \\
\text { Frequency }(\%)\end{array}$} \\
\hline Sites: & $\begin{array}{l}\text { treatment } \\
\text { control }\end{array}$ & $\begin{array}{l}37 \\
27\end{array}$ & $\begin{array}{l}24 \\
24\end{array}$ & $\begin{array}{l}38 \\
33\end{array}$ \\
\hline \multicolumn{5}{|c|}{$\begin{array}{l}\text { Litter Encounter } \\
\text { Frequency }(\%)\end{array}$} \\
\hline Sites: & $\begin{array}{l}\text { treatment } \\
\text { control }\end{array}$ & $\begin{array}{l}28.5 \\
16\end{array}$ & $\begin{array}{l}17 \\
19\end{array}$ & $\begin{array}{l}9.5 \\
27\end{array}$ \\
\hline \multicolumn{5}{|c|}{$\begin{array}{l}\text { Tree Crown Cover } \\
\text { in } 1,076 \text { square feet }(\%)\end{array}$} \\
\hline Sites: & $\begin{array}{l}\text { treatment } \\
\text { control }\end{array}$ & $\begin{array}{r}3 \\
11\end{array}$ & $\begin{array}{l}10 \\
15\end{array}$ & $\begin{array}{r}2 \\
11\end{array}$ \\
\hline \multicolumn{5}{|c|}{$\begin{array}{l}\text { Number of Trees } \\
\text { in } 1,076 \text { square feet }\end{array}$} \\
\hline Sites: & $\begin{array}{l}\text { treatment } \\
\text { control }\end{array}$ & $\begin{array}{l}3 \\
7\end{array}$ & $\begin{array}{l}4.5 \\
7\end{array}$ & $\begin{array}{l}3 \\
8\end{array}$ \\
\hline
\end{tabular}

on in the herbicide treatment, young pinyons were more plentiful and resulted in higher mean basal area, but less ground cover. The most effective treatment against woody shrubs was the herbicide with $0 \%$ cover of turbinella oak over the 656 foot transect, compared to a $34 \%$ cover of turbinella oak on the control transect in this same treatment.

\section{Prescribed Fire Treatment}

The herbaceous cover measured on the fire site was comprised of native species, which were encountered in similar quantities on the treatment and control sites. As with grass cover, forbs were sparse on both the treatment and control fire sites. The fire treatment and control sites had a greater variety of tree species diversity probably because of their close proximity to the next higher transition zone of the ponderosa pine forest. Here, fire had the most impact on the single needle pinyon. The Utah juniper and the alligator juniper fared much better on the prescribed fire site and were represented by more mature trees and fewer seedlings than the pinyon species. Considering the time frame between the execution of treatments and assuming the treatment sites are comparable, the prescribed fire treatment was more effective at suppressing woody shrubs for 16 years than the mechanical push treatment.

\section{Mechanical Push Treatment}

On this site the combination of soil composition and shrub and tree cover appear to have effectively precluded grass establishment. Bare soil was common among dense turbinella oak and manzanita stands. The push control area exhibited a similar vegetation/bare soil structure between clusters of shrub and tree (pinyon-juniper) species. The presence of bare soil (soil unoccupied by herbaceous cover, litter, or woody species) was common in all three treatment and control areas, however it was more common between dense shrubby vegetation in the push treatment. At the time of evaluation on this site the weeping lovegrass and yellow blossom sweet clover, seeded during the initial treatment, were very sparse. The push treatment most effectively reduced tree canopy cover by indiscriminately eliminating all the mature trees that allowed understory shrub species to become dominant. On the pushed site, tree seedlings were abundant and widely spaced. Of these seedlings, the Utah juniper was more common than the single needle pinyon.

Tree crown cover for all treated areas was higher in the corresponding control sites, which displayed a greater abundance of older, larger trees, and therefore better developed tree canopies. The analysis of all three treatments (herbicide, fire, and push) revealed a significant lack of mature tree species, indicating effective control of these larger canopy woody species since treatment was initiated.

Tree dominance was determined by mean basal area. The maximum number of trees per 1,076 square feet (seedlings over 5 feet tall and mature trees) in the treatments was approximately half that of the control sites.

Of the seven species of woody shrubs identified on the three pair of sites surveyed, turbinella oak was by far the most prevalent species in all control and treatment areas followed by squawbush and wright's silktassel. Woody shrub cover averaged $48 \%$ on the control transects and $31 \%$ on the treatment transects.

\section{Rangeland Management Implications}

This study suggests that some sites are very stable within the woody plant community type and will not shift toward a more desirable herbaceous community even after a dramatic disturbance, although continued application of the particular treatment may have yielded different results.

The desert grassland communities of central and northern Arizona are generally found in alluvial, depositional soils, while chaparral and juniper-pinyon woodland vegetation is typically found on rocky soils developed in situ. The fractured sub-surface geology and rocky, shallow soil conditions formed from granitic parent material are prevalent in the Santa Maria Mountains of west central Arizona. This factor may play a key role in favoring the evergreen shrubs and trees while limiting the establishment of grasses and other herbaceous vegetation. The abundance of bare soil may be an indicator of limited soil organic material.

Traditional rotational grazing on pastures on the northeastern side of the Santa Maria Mountains, including the three study sites, has continued since treatments were performed. Efforts to achieve a more consistent herbaceous cover on the landscape that includes the study sites, were most effective on the herbicide treatment. The dominant presence of introduced annual grass species has resulted in more unpalatable, nutritionally inferior grass species and a limited 
presence of other native grass diversity. However, considering this small area lies within a dense shrub cover on a working cattle ranch, this may be viewed as a desirable outcome because of the increase in herbaceous forage production.

Management objectives that concern activities such as grazing, fire suppression and tree harvesting may be undertaken with consideration for the pattern of local community development. Attempting to arrest succession cannot be accomplished unless the necessary conditions exist which favor the desired stage of development. Although the intended outcome of a stable, productive herbaceous community was not fully achieved in any of the three disturbance treatments, the dynamics of the pinyon-juniper and chaparral community are better understood. The establishment of a desired permanent state that is contrary to the natural momentum of the vegetation community does not appear to be possible in the region where this research was conducted.

Results from this project suggest that fire may promote a more equal distribution of shrub, tree and herbaceous cover that would enhance forage production and support a more diverse ecosystem structure in this plant community.

Some have suggested that juniper has encroached on grasslands in the Southwest in the last century. Our results suggest that the Santa Maria pinyon-juniper community is not the margin of juniper range but rather well within its habitat type. Limited soil development, parent material type and the inherent lack of organic matter suggests that this area may never have supported a consistent herbaceous plant community, except for the areas located at or near the base of the Santa Maria Mountains which are characterized by more developed soils on alluvial parent material.

\section{References and Further Readings}

Branson, F.A. 1985. Vegetation changes on Western rangelands. Soc. Range Manage. Denver, Colo.

Covington, W.W. and L.F. Debano. 1990. Effects of fire on pinyon-juniper soils. p.78-86. In: USDA For. Ser. Gen. Tech. Rep. RM-191.

Everett, R. L. and S.H. Sharrow. 1983. Response of understory species to tree harvesting in pinyon-juniper woodlands. P. 62-66 In: USDA For. Serv. Gen. Tech. Rep. RM-191.

Ffolliot, P.F. 1990. Opportunities for fire management in the future. p. 152-167. In: USDA For. Serv. Gen. Tech. Rep. RM-191.

Gordon, B.R., G.P. Parrot and J.B. Smith. 1992. Vegetation changes in northern Arizona: the Alexander Gardner Photos. Rangelands 14 (6): 308-319.

Hastings, J.R. and R.M. Turner. 1965. Changing mile. Univ. Arizona Press, Tucson, Ariz.

Johnsen, T. N. 1962. One seed juniper invasion of northern Arizona grasslands. Ecological Mon. 32(3): 187-205.

Meeuig, R.O. 1983. Stand dynamics and management alternatives for pinyon-juniper woodlands. P.172-175. USDA For. Ser. Gen. Tech. Rep. Int-157.

McClaran, M. P. and T.R. Van Devender, Editors. 1995. The desert grassland. Univ. Arizona Press, Tucson, Ariz.

Mueller- Dombois D. and H. Ellenberg. 1974. Aims and methods of vegetation ecology. John Wiley and sons, New York, N.Y.
Pieper, R. D. and R.D. Wittie. 1990. Fire effects in southwestern pinyon and juniper vegetation. p. 87-93. In: USDA For. Ser. Gen. Tech. Rep. RM-191.

Shaw, H. 1995. Vegetation changes in the central Arizona highlands, 1851-1995. General Wildlife Services, Chino Valley, Ariz.

Stanton, N. L. 1988. The underground in grasslands. An. Rev. of Ecol. Syst. 19:573-589.

Statistical Analysis Institute, Inc. 1990. JMP Users Guide. SAS Institute Inc., Cary, N.C.

Stephenson, N. L. 1990. Climatic control of vegetation distribution: a role of the water balance. The American Naturalist 135(5): 649-670.

Van Devender, T. R. and G. Spaulding. 1979. Development of vegetation and climate in the southwestern United States. Science 204(18):701-710.

Vavra, M., W.A. Laycock and R.D. Pieper, Editors. 1995. Ecological implication of livestock herbivory in the west. Soc. Range Manage., Denver, Colo.

Westoby, M., B. Walker and I. Noy-Meier. 1989. Opportunistic management for rangelands not at equilibrium. J. Range Manage. 12:266-274.

Acknowledgments: The completion of this project would not have been possible without the personal and technical assistance provided by the following individuals: Jay Ebe, Lisa Floyd - Hanna, Thomas Flieschner, Dennis and Deborah Moroney from the Cross U Ranch, Harley Shaw, and others.

Authors are biologist, National Park Service, Lava Beds National Monument, Tulelake, California 96134; and Professor, Environmental Studies Program, Prescott College, Prescott, Arizona 86301. At the time of research, the primary author was a graduate student in the Master of Arts Program, Prescott College, Prescott, Arizona. 